\title{
Water Restriction and Its Effect on Blood Hormones, Minerals and Metabolite in Baladi Goats
}

\author{
Mona A. El Khashab, A. I. Semaida and Masouda A. Abd El-Ghany* \\ Department of Animal Production (Animal Physiology) Faculty of Agriculture, \\ Fayoum University, Egypt \\ *Corresponding author
}

\begin{tabular}{|l|}
\hline K e y w o r d s \\
$\begin{array}{l}\text { Water restriction, goat, } \\
\text { Water balance, Blood } \\
\text { metabolites, } \\
\text { Thermoregulatory } \\
\text { response }\end{array}$ \\
\hline Article Info \\
\hline $\begin{array}{l}\text { Accepted: } \\
\text { 07 February } 2018 \\
\text { Available Online: } \\
\text { 10 March } 2018\end{array}$ \\
\hline
\end{tabular}

\section{A B S T R A C T}

The aim of this study was to investigate the effect of $50 \%$ water restriction on blood hormones, minerals and metabolite in baladi goats during summer months (June August). Ten non-pregnant and non-lactating balididoes (1.5-2 years old and average BW $=23.4 \pm 1.3 \mathrm{~kg}$ ), divided equally into two groups of 5 does each. The first group (treated) received $50 \%$ of water requirements (G1) while the other assumed as control (G2) (ad libitum water). Temperature - humidity index (THI) was calculated. Body weight (BW) and thermoregulatory response, rectal temperature (RT) andrespiration rate (RR) were recorded. Blood serum metabolites and mineral (total protein (TP), albumin (Alb), globulin (Glb), triglycerides (TG), cholesterol (Chol), glucose (Glu), $\mathrm{Na}^{+}, \mathrm{CL}^{-}$and $\mathrm{K}^{+}$) were determined. Kidney (creatinine and urea) and liver (ALT, AST) function and serum hormones (Triiodothyronine $\left(\mathrm{T}_{3}\right)$, thyroxin $\left(\mathrm{T}_{4}\right)$, aldosterone (Ald), progesterone $\left(\mathrm{P}_{4}\right)$ and estradiol $\mathrm{E}_{2}$ ) were measured and Haematological parameters (CBC) were assayed.Blood biochemical analysis indicated that the blood serum albumin, cholesterol, triglycerides, $\mathrm{Na}^{+}, \mathrm{K}^{+}, \mathrm{Cl}^{-}$, ALT, AST, Create and urea were not affected by water restriction. It was also, no changes in serum hormones were observed in water restricted does. Although, serum total protein and globulin were higher $(\mathrm{P}<0.05)$, serum glucose was significantly reduced $(\mathrm{P}<0.05)$ in treated goats. Blood picture as affected by treatment showed an increase $(\mathrm{P}<0.05)$ in $\mathrm{MCHC}$ and decrease in $\mathrm{HT}, \mathrm{MCV}$ and Platelets while $\mathrm{Hb}, \mathrm{MCH}$, WBCs and RBCs were not affected. It is concluded that baladi goats can easily survive under semi-arid areas.

\section{Introduction}

Water is considered one of the most important substances or nutrients, which consume in larger quantity than other nutrients by livestock (Mustafa et al., 2010) its covers almost $98 \%$ of the molecules in the animal organism (NRC, 2001). Water is already scarce for more than a billion people on the planet. If urgent measures are not adopted, one-third of the population may be without suitable water for consumption by 2025 (UNESCO, 2006). By 2055, 64\% of the world's population will be living in waterstressed basins and 33\% in areas of absolute water scarcity (Schlink et al., 2010 and Steinfeld et al., 2006). Water rarity is growing in progress problem in arid and semiarid 
regions with global warming and changes patterns of rainfall, which affect water resources, feed quality and quantity in addition to increase of heat stress. These challenges cause abroad range of physiological responses in sheep leading to adverse effects on production, immunity and welfare (Jaber et al., 2011).

Electrolyte and osmolality are affected by water stress. During water deprivation, hyperosmolality occurs as plasma volume reduces. $\mathrm{Na}^{+}$and $\mathrm{Cl}^{-}$electrolyte concentration mainly increased in water stress (Qinisa et al., 2011). To maintain $\mathrm{Na}^{+}$balance in the body, animal increased their retention of $\mathrm{Na}^{+}$. Some workers reported that higher renal retention is because of aldosterone (Ashour and Benlamlih 2001), whereas others stated the effect of vasopressin (McKinley et al., 2000). These reports suggested that vasopressin increased in dehydrated state.

Small ruminants, especially sheep and goats, have social and economic importance in the entire world. Information about feeding habits and nutrient requirements of these animals is essential for managing their welfare and for contributing to the livelihoods of people that depend on them. Adequate nutrition and management of these small ruminants are important for their maintenance to different ecosystems from the Arctic Circle to the Sahara desert (NRC 2007).

Water sources to goats include drinking water, dietary water (feed), and metabolic water from catabolism of nutrients (Araújo et al., 2010), where water is taken by goats intermittently and lost continuously in sweat, transpiration, urination and defecation.

This study aim to investigate if baladi goats can survive living in restricted water areas without being physiologically (hormones, minerals and others) affected.

\section{Materials and Methods}

This study was contacted at Demo area (semiarid desert), Experimental station belongs to Animal Production Farm, Faculty of Agriculture, Fayoum University, EL-Fayoum governorate, Egypt.

Ten healthy non-pregnant and non-lactating does(1.5-2 years old and $23 \pm 1.3 \mathrm{~kg}$ body weight) were equally divided in two groups, water restriction $50 \% \quad(\mathrm{G} 1)$ and control (G2).Goats were maintain in semi-open pens and feed concentrate mixture and Wheat straw. 60: $40 \%$ according to NRC (1985) during summer months (June-Agust).

Daily ambient temperature and relative humidity (RH \%) were measured to calculate Temperature Humidity index (THI) according to Hahn (1997) formula where

$$
\mathrm{THI}=\left[0.81 \mathrm{db}^{0} \mathrm{C}+\mathrm{RH}\left(\mathrm{db}^{0} \mathrm{C}-14.4\right)+46.4\right]
$$

Where: db. - dry bulb temp $\left({ }^{0} \mathrm{C}\right), \mathrm{RH}$ : relative humidity (RH, \%) /100.

Which refer to THI through experiment were 90.52

Body weight (BW), rectal temperature and respiration rate were recorded weekly at 10.00 a.m. before the distribution of the meal. Rectal temperature was measured using digital thermometer and respiration rate (breaths/min) was measured by counting the flank movements using stopwatch.

Blood samples were weekly withdrawn from a jugular vein of fasted does and blood serum were obtained and stored at $-20^{\circ} \mathrm{Cfor}$ hormonal and biochemical analysis. Serum metabolites, total protein (TP), albumin (Alb), glucose (Glu), cholesterol (chol), triglycerides (TG) were determined according to (Cannon, 1974), (Beng and Lim, 1973), (Howanitz and 
Howantiz 1984), (Burtis et al., 2006), (Scheleter and Nussel 1975) respectively, while globulin (glob) were calculated by subtracting serum Alb from TP. Where serum minerals $\left(\mathrm{Na}^{+}, \mathrm{K}^{+}\right.$and $\left.\mathrm{Cl}^{-}\right)$, liver and kidney function were measured according to (Trinder, 1951), (Sunderman and Sunderman 1958), (Burtis, 1999) and (Reitman et al., 1957) respectively. Hormonal profile (Ald, T3, T4, E2 and P4) by commercial radioimmunoassay (RIA) kit of Diagnostic products corporation (DPC) Los Angeles, USA. According to Mayes, (1970). Another blood samples were collected to haematological parameters which estimated according to Hawk et al., (1974).

The statistical analysis was carried out using SPSS software program, version 21 (IBM, Chicago). Level of statistical significance was set at $\mathrm{P}<0.05$. The model used for the present experiment was as follows:

$\mathrm{Y}_{\mathrm{i}}=\mu+\mathrm{W}_{\mathrm{i}}+\mathrm{e}_{\mathrm{i}}$

Where, $\mathrm{Y}_{\mathrm{i}}$ is dependent variables in the study

$\mu$ is overall mean

$\mathrm{W}_{\mathrm{i}}$ is the effect of water mood (treatment) $(\mathrm{i}=1,2)$

$\mathrm{e}_{\mathrm{i}}$ is the error

\section{Results and Discussion}

\section{Thermoregulatory parameters and body weight}

Insignificant differences were noticed in rectal temperature of water restricted group compared to control group, where the average of RT were 38.93 and $38.98^{\circ} \mathrm{C}$ respectively Table 1. The slightly changes in RT of restricted goats due to the adaptive response of Baladi goats to the breeding environment that serves to reduce water loss through mechanisms of thermoregulation for the defence from heat (Ghanem et al., 2008). Furthermore, water restriction caused a decrease $(\mathrm{P}<0.05)$ in respiration rate by $6 \%$ compared with ad libitum water intake (Table 1). Moreover, the reduction of respiratory acts under water restriction is one of many defence mechanisms which the animal employs to prevent the loss of water and dehydration through pulmonary evaporation (El- Khashab, 2002).

Analysis of the results in (Table 1) indicated that there was body weight loss due to water restriction. Where water restriction caused a decrease significantly in body weight by $7.54 \%(1.86 \mathrm{~kg})$ compared with control group. The weight loss may be due to body water loss and consequent mobilization of fat (and possibly muscle) used for energy metabolism (Jaber et al., 2004). These results agreed with Kumar et al., (2016) who found the final body weight was lower in water-restricted animals.

\section{Blood serum metabolites}

Insignificant increase in Chol, $\mathrm{Alb}$ and TG were noticed in water restricted does (Table 2). Water restriction caused an increase in serum total protein and globulin by $13 \%$ and $14.12 \%$ respectively compared with ad libitum water intake. The observed significant increase in serum total proteins in this study might be due to reduction in plasma volume caused by dehydration (Khalil et al., 1990). The increase in serum total proteins might cause an increase in plasma colloid osmotic pressure (Cole, 2000). Moreover, the increase in globulin due to water deprivation might be due to either mobilization of proteins from the lymphatics to the blood circulation or to the activation of the lymphoid tissue to produce antibodies (Shoukry, 1981).

Water restriction caused a decrease in serum glucose concentration by $10.90 \%$ compared 
with control group. This result agreed with Kumar et al., (2016) found that the glucose and cholesterol levels were lower $(\mathrm{P}<0.05)$ in $20 \%$ less than ad libitum water intake compared with control.ad libitum water. Some reports stated that glucose metabolism decreases because of decreased propionate production in the rumen as feed intake reduces following water restriction.

An insignificant increase of 1.09, 10.89 and $17.37 \%$ in water restricted does in Alb, Chol and TG respectively. The increase in serm TG and Chol in this study might be due to reduction in plasma volume caused by dehydration (Khalil et al., 1990). The increase in cholesterol level after water restriction is mainly due to fat metabolism because of low energy intake (Jaber et al., 2013).

Serum Alanine amino transferase (Alt) and Aspartate aminotransferase

(AST) concentration were not affected by water restriction where the average mean showed the same.

\section{Serum mineral profile}

The current results indicated that slightly increase of $\mathrm{Na}^{+}$and $\mathrm{Cl}^{-}$and decrease in $\mathrm{K}^{+}$ level in water restricted does but the differences in both case are insignificant (Table 3). This increase might be due to sweating rate and excretory pattern. Also the ability of goat's kidney to concentrate urine and conserve water caused variations in blood volume as proposed by Ashmawy and Ibrahim (1999).

In addition this increase in $\mathrm{Na}^{+}$and $\mathrm{Cl}^{-}$in restricted goat may be accompanied by an increase of blood osmolality and osmosis balance as result of dehydration as previously noticed in $72 \mathrm{~h}$ water deprivation, which is preceded by losses from intracellular pool and decrease in extracellular water volume (Cole
2000). The increase in $\mathrm{Na}^{+}$when sheep deprived from water might be due to adrenal response to this stress in an attempt to maintain plasma volume or probably due to a decrease in extracellular fluid volume (more and sahni, 1980). The slight decrease in serum $\mathrm{K}^{+}$in goats might be due to $\mathrm{K}^{+}$elimination in the urine.

Serum Urea and Creatinine of water restricted and control of goats presented in Table 3 the average concentration of serum urea and create was insignificantly higher (55 and 53 $\mathrm{mg} / \mathrm{dl})$ for urea and $(1.42$ and $1.33 \mathrm{mg} / \mathrm{dl})$ for create in water restricted and control group respectively. Water deficiency leads to increased water reabsorption at the nephron level; consequently, increased urea reabsorption is expected as it is a highly permeable molecule. The increase in serum urea level may also be related partially to increase in secretion of the hormone arginine vasopressin (AVP).

It has been reported that water deprivation increased (AVP) level in goats (Olsson and Dahlborn, 1989) and this would have opposed loss of urea as (AVP) promotes urea reabsorption in the kidney (Meintjes and Engelbrecht, 2004). The rise in urea level could also be associated with catabolism of body proteins during dehydration (Houpt, 2004).

Osbaldiston (1971) reported that hypovolaemia due to water insufficiency is expected to cause a decrease in renal blood flow, thus leading to a decreased filtration rate; in fact, $95 \%$ of creatinine, the final metabolite of create, is of muscular origin and it is excreted by the kidneys in proportion to the muscle mass and to its rate of proteolysis. When kidney water stress leading to slower glomerular filtration and reabsorption of urea excretion affects kidney excretion function (Kataria and Kataria, 2007). 
Table.1 Rectal temperature, respiration rate and body weight of Baladi goats under ad libitum water and restriction $50 \%$

\begin{tabular}{|l|c|c|c|}
\hline Parameters & Control & Restricted water & sig \\
\hline RT $\left({ }^{\circ} \mathbf{C}\right)$ & $38.93 \pm 0.04$ & $38.98 \pm 0.05$ & 0.15 \\
\hline RR(rpm) & $36.97 \pm 0.95$ & $34.77 \pm 0.82$ & 0.02 \\
\hline BW(kg) & $24.66 \pm 0.34$ & $22.80 \pm 0.29$ & 0.000 \\
\hline
\end{tabular}

R: rectal temperature $\mathrm{BW}$ : body weight

RR: respiration raterpm: Revolution per minute

Table.2 Peripheral blood serum metabolites and liver function of Baladi goats under ad libitum water and restriction $50 \%$.

\begin{tabular}{|c|c|c|c|}
\hline Parameters & Control & Restricted water & sig \\
\hline TP(g/dl) & $8.38 \pm 0.22$ & $9.47 \pm 0.24$ & 0.002 \\
\hline Alb (g/dl) & $3.07 \pm 0.15$ & $3.38 \pm 0.15$ & 0.15 \\
\hline Glb(g/dl) & $5.31 \pm 0.14$ & $6.06 \pm 0.36$ & 0.002 \\
\hline Glu(mg/dl) & $61.20 \pm 1.65$ & $54.53 \pm 1.40$ & 0.005 \\
\hline Chol (mg/dl) & $80.20 \pm 3.43$ & $88.93 \pm 3.82$ & 0.10 \\
\hline TG (mg/dl) & $73.67 \pm 6.81$ & $86.47 \pm 10.13$ & 0.30 \\
\hline AlTU/L & $21.93 \pm 0.81$ & $21.33 \pm 0.95$ & 0.64 \\
\hline AstU/L & $72.67 \pm 5.44$ & $73.33 \pm 5.63$ & 0.93 \\
\hline
\end{tabular}

TP: Total protein Alb: Albumin Chol: Cholesterol

Glb: globulin Glu: Glucose TG: Triglyceride

AlT: Alanine amino transferase Ast: Aspartate amino transferase

Table.3 Peripheral blood serum mineral profile and kidney function of Baladi goats under ad libitum water and water restriction $50 \%$

\begin{tabular}{|c|c|c|c|}
\hline Parameters & Control & Restricted water & sig \\
\hline $\mathrm{Na}^{+}(\mathrm{mEq} / \mathrm{L})$ & $150.80 \pm 2.79$ & $155.67 \pm 2.70$ & 0.22 \\
\hline $\mathrm{CL}(\mathrm{mEq} / \mathrm{L})$ & $108.06 \pm 1.25$ & $110.01 \pm 1.41$ & 0.31 \\
\hline $\mathrm{K}^{+}(\mathrm{mEq} / \mathrm{L})$ & $4.14 \pm 0.18$ & $4.01 \pm 0.21$ & 0.66 \\
\hline urea(mg/dl) & $53.00 \pm 1.86$ & $55.00 \pm 1.85$ & 0.45 \\
\hline Creat $(\mathrm{mg} / \mathrm{dl})$ & $1.33 \pm 0.08$ & $1.42 \pm 0.11$ & 0.49 \\
\hline
\end{tabular}

$\mathrm{Na}^{+}$: Sodium ion $\mathrm{CL}^{-}$: Chloride ion

$\mathrm{K}^{+}$: Potassium ion create: creatinine

Table.4 Peripheral blood hormonal of Baladi goats under ad libitum water intake and water restriction $50 \%$

\begin{tabular}{|l|l|l|l|}
\hline Parameters & Control & Restricted water & sig \\
\hline Ald(pg/l) & $75.44 \pm 10.94$ & $78.13 \pm 7.99$ & 0.84 \\
\hline T3(ng/dl) & $112.17 \pm 7.021$ & $107.85 \pm 10.521$ & 0.75 \\
\hline T4(ug/dl) & $5.93 \pm 0.58$ & $6.083 \pm 0.44$ & 0.83 \\
\hline E2(pg/ml) & $9.71 \pm 1.50$ & $10.83 \pm 1.85$ & 0.64 \\
\hline P4ng/ml) & $3.18 \pm 0.92$ & $2.33 \pm 0.77$ & 0.84 \\
\hline
\end{tabular}

Ald: Aldosterone T3: Triiodothyronine T4: Thyroxine

E2: Estradiol P4: Progesterone 
Table.5 Complete blood picture CBCs of Baladi goats under ad libitum water intake and water restriction $50 \%$

\begin{tabular}{|c|c|c|c|}
\hline Parameters & Control & Restricted water & Sig \\
\hline HT\% & $21.05 \pm 0.94$ & $18.72 \pm 0.46$ & 0.03 \\
\hline Hb(g/dl) & $9.55 \pm 0.27$ & $9.71 \pm 0.26$ & 0.67 \\
\hline RBCs $\left(\mathbf{x} 10^{6} / \mu l\right)$ & $5.45 \pm 0.17$ & $5.23 \pm 0.11$ & 0.28 \\
\hline MCH $(\mathbf{p g})$ & $17.78 \pm 0.73$ & $19.70 \pm 1.25$ & 0.19 \\
\hline MCV $\left(\right.$ um $\left.^{3}\right)$ & $38.43 \pm 0.97$ & $35.92 \pm 0.70$ & 0.04 \\
\hline MCHC\% & $46.39 \pm 2.15$ & $53.68 \pm 1.74$ & 0.01 \\
\hline Platelet $\left(\mathbf{x} 10^{3} / \mu \mathrm{l}\right)$ & $323.65 \pm 9.94$ & $287.20 \pm 9.58$ & 0.01 \\
\hline WBC(x10 $/ \mu l))$ & $12.67 \pm 1.80$ & $13.23 \pm 0.96$ & 0.65 \\
\hline Neutrophil & $15.46 \pm 1.31$ & $15.09 \pm 1.47$ & 0.85 \\
\hline lymphocyte & $73.77 \pm 1.54$ & $73.64 \pm 1.89$ & 0.96 \\
\hline monocyte & $6.45 \pm 0.40$ & $6.69 \pm 0.49$ & 0.71 \\
\hline Eosinophil & $4.28 \pm 0.21$ & $4.54 \pm 0.23$ & 0.41 \\
\hline
\end{tabular}

Hb: Haemoglobin HT: Haematocrit

RBCs: Red Blood Cells WBCs: White Blood Cells

MCH: Mean corpuscular hemoglobin MCV: Mean corpuscular volume

MCHC: Mean corpuscular hemoglobin concentration

\section{Blood hormones}

Table 4 shows that insignificant differences were noticed in $T_{3}$ and $T_{4}$ level of water restriction group compared to control group, where the average of $\mathrm{T}_{3}$ and $\mathrm{T}_{4}$ were $(112.17$ and $107.85 \mathrm{ng} / \mathrm{dl})$ and $(5.93$ and $6.08 \mathrm{ug} / \mathrm{dl})$ These results agreed with (Jaber et al., 2011) who found $\mathrm{T} 3$ and $\mathrm{T} 4$ level decreases in water-restricted animals.

The reason of reduced $T_{3}$ in case of water stress refers lower metabolic state due to dehydration and decreased feed intake (Jaber et al., 2013). The possible reason behind decreased thyroid hormone activity is attributed to the animals' attempt to minimize water loss by decreasing metabolism (Olsson 2005).

Analysis of the results in Table 4 indicated that water restriction has barely affected serum aldosterone concentration in goats. These results agreed with $\mathrm{Li}$ (2000) who found plasma aldosterone was not affected by restricted group. Also, water restriction did not significantly increase plasma osmolality in the warm environment (Silanikove and Tadmor 1989).

It was obviously observed that there is insignificant increase and decrease in $E_{2}$ and $\mathrm{P}_{4}$ in goats due to water restriction in this study Table 4. However, in another research estrogen and progesterone showed a reverse trend for the effect of water restriction (Kumar et al., 2016).

It is well known that endocrine responses to stress, in general, work toward suppressing productive functions, such as growth and reproduction, in favor of maintenance and survival (Rivest and Rivier, 1995). The last research referred the serum estradiol in the water-restricted groups may be attributed to the diminished ovarian follicular development caused by suppressed peripheral level of gonadotropins (Lechner-Doll et al., 1995). 


\section{Haematological parameters}

Water restriction caused a decrease in hematocrit (HT) This decrease in hematocrit values during the water restriction is partially due to a decrease in circulating erythrocytes (Nejad et al., 2014), MCV and Platelets by $11,6.53$ and $11.26 \%$ respectively compared with control group (Table 5). While, an increase of $15.7 \%$ in $\mathrm{MCHC}$ of treated goat was noticed compared with ad libitum water intake may be due to a decrease in $\mathrm{Ht}$ value.

The present results indicated that water restriction has barely affected $\mathrm{Hb}, \mathrm{MCH}$ and RBCs count in goats. This result agreed with Nejad et al., (2014) who found that RBCs values remained unchanged under goes water restriction regime. Moreover, insignificant differences were noticed in WBCs count and it differential of water restriction group compared to control group, which in parallel to Nejad et al., (2014) who reported concentrations of white blood cell were not different among treatment groups.

It could be concluded that blood serum hormones, mineral profile, metabolites and liver kidney function were not affected by water restriction in goats so goat may survive at $50 \%$ restriction of water without affecting physiological indices and then their production.

\section{References}

Alamer, M. and Al-hozab, A. (2004). Effect of water deprivation and season on feed intake, body weight and thermoregulation in Awassi and Najdi sheep breeds in Saudi Arabia. J. Arid Environ, 59: 71-84.

Araújo, G. G. L., Voltolini, T. V., Chizzotti, M. L., Turco, S. H. N., DeCarvalho, F. F. R. (2010). Water and small ruminant production. Revista Brasileira de Zootecnia, vol. 39, p: 326-336.
Ashmawy, Neama. A. and Ibrahim, S. A (1999). Major plasma cations and aldosterone concentration of sheep and goats as affected by some environmental conditions. Vet. Med. J., Giza, 74(2):213.

Ashour G, Benlamlih S (2001) Adaptation of Mediterranean breeds to heat stress and water deprivation. In: Guessous F, Rihani $\mathrm{N}$, Ilham A (eds) Livestock production and climatic uncertainty in the Mediterranean: proceedings of the Joint ANPA- EAAPCIHEAM- FAO symposium. Wageningen Press, Wageningen.

Beng, C.G. and K.L. Lim (1973). Colorimetric determination of albumin in serum. Am. J.Clin.Path., 59:14- 21.

Burtis, A., (1999). Text Book of Clinical Chemistry. $3^{\text {rd }}$ Ed, AACC, Press.

Burtis, C.A, E, R. Ashwood and D.E. Bruns (2006). Tietz Textbook of Clinical Chemistry and Molecular Diagnostics. 4th ed., Elsevier Saunders, St. Louis., pp 942- 956.

Cannon, D.C. (1974). Examination of seminal fluid. In: Todd-Sanford Clinical Diagnosis by Laboratory Methods, (31): 1201-1207.

Cole. N. A. (2000). Changes in postprandial plasma and extracellular and ruminal fluid volumes in weathers fed or unfed for 72 hours. J. Anim. Sci. 78-216.

El- Khashab. Mona, A., (2002). Physiological responses to water deprivation in ossimi sheep. Egypt. J. Basic. Appl. Physiol., 1(1): 63 - 82.

Ghanem, A. M., Barbour, E. K., Hamadeh, S. K., Jaber, L. S. and Said, M. A. (2008). "Physiological and chemical responses in water-deprived Awassi ewes treated with vitamin C,'J. of Arid Environments, vol. 72, pp. 141-149.

Hahn, G. L. (1997). Dynamic responses of cattle to thermal heat loads. J. Anim. Sci., 77: 10-20.

Hawk, P.B., Oser, B. L. and Summerson, W. H. (1974). Practical physiological chemistry. 12th Ed., Churchill Ltd., London. 
Houpt, R.T., (2004). Water and electrolytes. In: Duke's Physiology of Domestic Animals (Editor: W.O Reece), 12 edition. Comstock Publishing Associates, Cornell University Press, Ithaca, London, pp: 1226.

Howanitz, P.J. and J.H. Howantiz (1984). In: Clinical Diagnosis and Management by laporatory Methods, $17^{\text {th }}$ ed., J.B. Henry, (Ed). W.B. Saunders, Philadelphia, PP. 168.

Jaber LS, Hanna N, Barbour EK, Abi Said M, Rawda N, Chedid M, Hamadeh SK (2011) Fat mobilization in water restricted Awassi ewes supplemented with vitamin C. J Arid Environ 75:625628.

Jaber, L. S., Habre, A., Rawda, N., Abid Said, M., Barbour, E. K. and Hamdeh, S. (2004). The effect of water restriction on certain physiological parameters in Awassi sheep. Small Ruminant Research. 54(1-2):115-120.

Jaber, L., Chedid, M., Hamadeh, S., 2013.Water stress in small ruminants. In: Akinci, S. (Ed.), Responses of Organisms to Water Stress. In Tech, Janeza Trdine 9, 51000 Rijeka, Croatia, pp. 115-149.

Kataria N, Kataria AK (2007). Compartmental water management of Marwari sheep during dehydration and rehydration. Vet Arch 77:551-559.

Khalil, M. H, H. H. Khalifa, H. M. El-Gabbas and M. S. H. Abdel-Fattah (1990). The adaptive response to water deprivation in local and crossbred sheep. Egyptian J. Anim. Prod., 27:195.

Kumar, D., De, K; Singh, A. K., Kumar, K., Sahoo, A., Naqvi, S. M. K. (2016). Effect of water restriction on Physiological responses and certain reproductive traits of malpura ewes in a semiarid tropical environment. J. Vet. Behav. 12: 54-59.

Lechner-Doll, M., Von Engelhardt, W., Abbas, A.M., Mousa, H.M., Luciano, L., Reale, E., 1995. Particularities in forestomach anatomy, physiology and biochemistry of camelids compared to ruminants. In: Tisserand, J.L. (Ed.), Elevage et al., imentation du dromadairee Camel production and nutrition. Options méditerranéennes, Serie B: Etudes et Recherches. 13. 19-32. CIHEAM, Paris, pp. 19-32.

Li, B. T., Christopherson, R. J. and Cosgrove, S. J. 2000. Effect of water restriction and environmental temperatures on metabolic rate and physiological parameters in sheep. Can. J. Anim. Sci. 80: 97-104.

Mayes, D. (1970). Radio immuno assay for plasma aldosterone. J. Clin. Endocrinol. Metab, 30: 682.

McKinley MJ, Evered MD, Mathai ML (2000). Renal $\mathrm{Na}$ excretion in dehydrated and rehydrated adrenalectomized sheep maintained with aldosterone. Am J Physiol Regul Integr Comp Physiol 279:17-24.

Meintjes, R.A. and H. Engelbrecht, (2004). Changes in the renal handling of urea in sheep on a low protein diet exposed to saline drinking water. Onderstepoort J. Veterinary Res., 79: 165-170.

More T, Sahni K L (1980). Effect of intermittent watering on milk production and lamb growth in Chokla ewes under semi-arid conditions. Indian Vet $\mathbf{J}$ 57:464-466.

Mustafa, Y. S. -Sulehrla, A. Q. K. -Muneer, M. A. -Munir, R. (2010). Effect of water restriction on the lymphoid organs and production of broilers. Biologia, vol. 56, 2010, p. 63-68.

National Research Council - NRC. 2001. Nutrient requirements of dairy cattle. 6.rev.ed. Washington, D.C., 381p.

National Research Council - NRC. 2007. Nutrient requeriments of small ruminants: sheep, goats, cervids, and new world camelids. Washington, D.C., 384p.

Nejada Ghassemi, J., Lohakare, J. D. Westb, J. W. Sung. K. I. (2014). Effects of water restriction after feeding during heat stress on nutrient digestibility, nitrogen balance, blood profile and characteristics in Corriedale ewes. Animal Feed Science and Technology 193:1-8. 
NRC, (1985). Nutritional Requirements of Sheep, National Research Council.6th Ed.

Olsson, K. and K. Dahlborn, 1989. Fluid balance during heat stress in lactating goats. Quarterly J. Experimental Physiology, 74(5): 645-659.

Olsson, K. (2005). Fluid balance in ruminants: adaptation to external and internal challenges. Ann N Y AcadSci 104:156161.

Osbaldiston GW (1971): The kidney: its function and evaluation in health and disease. In: Kaneko JJ, Cornelius CE (eds): Clinical Biochemistry of Domestic Animals. 2nd edn. Academic Press, New York. 2-28.

Qinisa MM, Boomker EA, Mokoboki HK (2011). Physiological responses of waterrestricted tswana and boer goats. Life Sci J 8:106-111.

Reitman, S. and S. Frankel., (1957).Photometric determination of SGOT and SGPT. American. J. Clin. Path., 28- 56.

Rivest, S., Rivier, C., 1995. The role of corticotropin-releasing factor and interleukin-1 in the regulation of neurons controlling reproductive functions. Endocr. Rev. 16, 177-199.

Scheleter, G and E. Nussel, (1975): Arbertsmed Sozialmed. Parcuatenucleusuate nucleusentimrd.10:25.

Schlink, A.C. Nguyen, M. L. and Viljoen, G.J. (2010).Water requirements for livestock production: a global perspective. Rev. sci. tech. Off. int. Epiz., 2010, 29(3), 603-619.

Shoukry, H. M. S. (1981): Adaptability of some local and foreign breeds of sheep under Egyptian environment. M.Sc. Thesis, Faculty of Agric., Al- Azhar Univ., Cairo, Egypt.

Silanikove, N. (2000): The physiological basis of adaptation in goats to harsh environments. Small Rumin. Res. 32:181-193.

Silanikove, N. and Tadmor, A. 1989.Rumen volume, saliva flow rate, and systemic fluid homeostasis in dehydrated cattle. Am. J. Physiol. 256: R809-R815.

Steinfeld, H., Gerber, P., Wassenaar, T., Castel, V., Rosales, M. and de Haan, C. (2006). Livestock's long shadow: environmental issues and options. Food and Agriculture Organization of the United Nations, Rome, 390 pp.

Sunderman, F.W.J. and F.W. Sunderman, (1958). A Turbidimetric method for potassium determination. Am. J. Clin. Pathol. 29: 95.

Trinder, P., (1951). A colorimetric method for sodium determination. Analyst, 76: 596.

United Nations Educational, Scientific and Cultural Organization - UNESCO, 2006 World water development reports 2 Water, a shared responsibility. Paris: Berghahn Books; New York.

\section{How to cite this article:}

Mona A. El Khashab, A.I. Semaida and Masouda A. Abd El-Ghany. 2018. Water Restriction and Its Effect on Blood Hormones, Minerals and Metabolite in Baladi Goats. Int.J.Curr.Microbiol.App.Sci. 7(03): 747-755. doi: https://doi.org/10.20546/ijcmas.2018.703.087 